10. Melnyk, I.A. (2005). Natsionalne vidrodzhennia v protsesi utverdzhennia suverenitetu Ukrainy [National revival in the process of asserting the sovereignty of Ukraine]. Zbirnyk naukovykh prats naukovo-doslidnoho instytutu ukrainoznavstva - Collection of scientific works of the Research Institute of Ukrainian Studies, T. IV, 59-73. Kyiv: Polihrafichnyi tsentr «Foliant» [in Ukrainian].

11. Myronchuk, Yu. (2005). Dyvosvit ridnoi movy u tvorchosti Dmytra Bilousa [Divine education of native language in the works of Dmitry Belous]. Ukrainoznavstvo - Ukrainian Studies, Chyslo 1, 246-254 [in Ukrainian].

12. Nezlamne smile [Unbreakable bold]. umoloda.kiev.ua. Retried from: http:www.umoloda.kiev.ua/number/1197/163/42534/ [in Ukrainian].

13. Tarovska, O. (2004). Istoriia stanovlennia NDIU yak vidzerkalennia utverdzhennia teorii ukrainoznavstva na terenakh Ukrainy $90-\mathrm{kh}$ rr. XX st. [History of NDIU formation as a reflection of the statement of the theory of Ukrainian studies in the territory of Ukraine of the 90s of the XX century]. Ukrainoznavstvo - Ukrainian Studies, Chyslo 1-2, 207-214 [in Ukrainian].

14. Tokar, L. (2004). Samoidentyfikatsiia v systemi samopiznannia y samotvorennia narodu [Self-identification in the system of self-knowledge and self-creation of the people]. Ukrainoznavstvo - Ukrainian Studies, Chyslo 1-2, 164-171 [in Ukrainian].

15. Tokar, L.K. (2005). Zmist ukrainoznavstva: systemno-funktsionalnyi pidkhid do strukturuvannia znan [Content of Ukrainian Studies: A System-Functional Approach to Knowledge Structuring]. Zbirnyk naukovykh prats naukovo-doslidnoho instytutu ukrainoznavstva - Collection of Scientific Papers of the Research Institute of Ukrainian Studies, T. IV, 24-32. Kyiv: Polihrafichnyi tsentr «Foliant» [in Ukrainian].

16. Usatenko, T.P. (2005). Ukrainoznavstvo: mifolohichnyi aspect [Ukrainian Studies: Mythological Aspect]. Zbirnyk naukovykh prats naukovo-doslidnoho instytutu ukrainoznavstvaCollection of Scientific Papers of the Research Institute of Ukrainian Studies, T. IV, 32-39. Kyiv: Polihrafichnyi tsentr «Foliant» [in Ukrainian].

17. Shevchenko, V. (2005). Filosofsko osvitnii potentsial ukrainoznavstva [Philosophical and educational potential of Ukrainian studies]. Ukrainoznavstvo - Ukrainian Studies, Chyslo 1, 69-74 [in Ukrainian].

18. Shkribliak, P. Rehionalna samobutnist hutsulshchyny $\mathrm{v}$ zahalnoukrainskomu konteksti: istoriia, suchasnyi stan, perspektyvy i problemy [Regional identity of the Hutsul region in the Ukrainian context: history, current state, prospects and problems]. Ukrainoznavstvo - Ukrainian Studies, Chyslo 1, 229-240 [in Ukrainian].

Одержано 23.04.2019.

УДК 323.15(091)(477)]:930.1(477)«199/201»

\section{Коцур Віталій,}

кандидат політичних наук, доцент, старший науковий співробітник відділу національних меншин,

kotsurv@ukr.net

https://orcid.org/0000-0001-6647-7678

Інститут політичних i етнонаціональних досліджень ім. І.Ф.Кураса НАН України, вул. Генерала Алмазова, 8. м. Київ, 01011.

\section{DOI https://doi.org/10.31470/2415-3567-} 2019-46-232-250

\section{Kotsur Vitalii,}

Candidate of Political Sciences, Assoc. Prof., Senior Research Scientist of the Department of National Minorities

kotsurv@ukr.net https://orcid.org/0000-0001-6647-7678

I.F. Kuras Institute of Political and EthnoNational Research of the National Academy of Sciences of Ukraine 
8, General Almazova St., Kyiv, Ukraine, 01011

\section{НАЦІОНАЛЬНІ МЕНШИНИ УКРАЇНИ В НАУКОВОМУ ДИСКУРСІ ВІТЧИЗНЯНИХ ДОСЛІДНИКІВ 90-Х РР. ХХ СТ. - ПОЧ. ХХІ СТ.}

У запропонованому історіографічному огляді проблематика національних меншин України дослідників 90-х рp. ХХ cm. - поч. ХХI cm. розглядається через низку проблемнозмістових блоків, які визначали пріоритети дослідницьких практик на тому чи іншому етапі українського державотворення під виливом внутрішніх $i$ зовнішніх чинників. $У$ дослідженні виявлено, шуо у наявному украӥнському та зарубіжному науковому дискурсі трунтовно $і$ багатогранно розкриваються національні меншини як суб'єкт украӥнського державотворення в умовах сочіально-політичних трансформачій, політичної нестабільності та зовнішньополітичних викликів 90-х рр. XX-поч. XXI cm. Водночас досі належним чином не репрезентовано великий спектр поглядів, думок, оцінок, які належать представникам національних меншин та етнічних груп, щзо й актуалізує подальші дослідницькі практики в нових історичних реаліях. На сучасному етапі розвитку України сформувалася сучасна плеяда учених з новим науковим мисленням в царині вивчення етнонаціональної проблематики, які прагнуть не лите об'єктивно ї̈ інтерпретувати, а й протистояти деструктивним силам, експансії ідеології "русского мира», відповідально прогнозувати майбутнє та орієнтуватися на практичні результати. Саме в орієнтації на практичні результати вбачається можлива площина продуктивної взаємодії історика $i$ влади в царині етнонаціональної проблематики в умовах міжнародних, соціальноекономічних і політичних викликів для Украӥни в XXI cm.

Ключові слова: національні меншини, етнонаціональна проблематика, зовнішньополітичні виклики, державотворення.

\section{NATIONAL MINORITIES OF UKRAINE IN THE SCIENTIFIC DISCOURSE OF UKRAINIAN RESEARCHERS OF 1990'S OF 20 CENTURY - BEGINNING OF 21 CENTURY}

In the proposed historiographical survey, the problems of national minorities of Ukrainian researchers of the 1990s 20 century - beginning of the 21 century are considered through a series of problematic and meaningful blocks, which determined the priorities of research practices at one or another stage of Ukrainian state formation under the influence of internal and external factors. The study revealed that in the existing Ukrainian and foreign scientific discourse, national minorities were thoroughly and multifacetedly revealed as a subject of Ukrainian state formation in the conditions of socio-political transformations, political instability and foreign policy challenges of the 1990s 20th century - beginning of the 21st century. At the same time, however, the large range of views, opinions, and assessments belonging to representatives of national minorities and ethnic groups is not adequately represented, which actualizes further research practices in the new historical realities. At the present stage of development of Ukraine formed a modern galaxy of scientists with new scientific thinking in the field of study of ethno-national issues, seeking not only to objectively interpret it, but also to resist destructive forces, expansion of ideology of the "Russian world", responsibly predict the future and practice. It is in the focus on practical results that the possible plane of productive interaction between the historian and the authorities in the field of ethno-national issues is seen in the context of international, socio-economic and political challenges for Ukraine in the 21 st century.

Keywords: national minorities, ethno-national issues, foreign policy challenges, state formation. 
Україна - поліетнічна держава, що знаходиться на перетині цивілізаційних впливів, зіткнення політичних, економічних, соціокультурних інтересів демократичних i тоталітарних держав XXI ст. Російська агресія проти України спонукала істориків у часовому вимірі сутнісно переосмислити українсько-російські, насамперед, міжнаціональні відносини на теренах нашої Батьківщини під кутом зору власних національних інтересів. Вітчизняні, зарубіжні історики помітили відвертий слід російських нафтодоларів і на європейському цивілізаційному просторі, а саме: у втручанні Росії у виборчі процеси за кордоном, створенні там антиукраїнської «п'ятої колони». Підкуп і шантаж західних політиків - один із інструментів впливу на національні меншини Закарпаття, Півдня України. «Гібридна війна» стала невід’ємною частиною російської зовнішньої політики, зокрема, в царині міжнаціональних відносин України. Національні меншини відіграють важливу роль в історії незалежної України. Етнонаціональне різноманіття в Україні певною мірою впливало на суспільно-політичні, культурні, економічні, конфесійні чи ідеологічні процеси всередині країни. Осмислення ролі національних меншин у всіх сферах суспільного, політичного життя України, як на загальнонаціональному, так і на регіональному рівні має не лише науково-пізнавальне, а й безпекове значення для країни, яка у військовому протистоянні з Російською Федерацією боронить європейські цінності, прогресивні надбання сучасного цивілізованого світу.

Об'єктом дослідження $є$ національні меншини як суб'єкт українського державотворення, визначальний чинник соціокультурного поступу, соціально-політичних трансформацій і водночас політичної нестабільності в умовах зовнішньополітичних викликів 90-х рр. XX - поч. XXI ст.

Предметом дослідження $є$ дискурс українських та зарубіжних науковців щодо ролі національних меншин України у державотворчих процесах 90-х pp. XX - поч. XXI ст.

Мета дослідження полягає в аналізі наукового дискурсу щодо місця i ролі національних меншин України в суспільно-політичних трансформаціях 90-х pp. XX ст. початку XXI століття.

Українські вчені тривалий час вивчають суспільно-політичні, правові, соціокультурні складники національних меншин як в цілому, так і окремих спільнот. Вагомим доробком у царині етнонаціональних відносин $є$ праці відомих українських дослідників I. Кураса, М. Панчука, О. Майбороди [43], О. Рафальського, Я. Калакури, В. Котигоренка, С. Макарчик, О. Антонюка, В.Британ, О. Висоцького, К. Колесникова, Г. Луцишин, В. Загорської-Антонюк, В. Наулка, Р. Коршук [28], Г. Лозко та інших.

Монографія І.Ф. Кураса «Етнополітика: Історія та сучасність. Статті, виступи, інтерв'ю 90-х років» у проблемно-хронологічному порядку синтезує статті, доповіді виступи 31991 р. 3 актуальних питань етнополітичного розвитку і гуманітарної сфери України в цілому [37], саме: $з$ того часу, коли започатковувалася українська етнополітика, iii нормативно-правова база, закладалися основи нового історіографічного покоління в царині етнополітики, яке сьогодні визначає стратегії української історичної науки.

Фундаментальним дослідженням, яке й досі становить значний історіографічний інтерес, є монографія «Національні меншини України у XX столітті: політико-правовий аспект» (М. Панчук, В. Войналович, М. Геник, О. Калакура, В. Котигоренко та ін.), у 6 розділах якої розглянуто питання національних меншин незалежної Української держави, зокрема, формування правового статусу етнічних меншин, їх культурно-громадська та релігійна діяльність, міжнародне визнання й етнополітичні виклики Автономної Республіки Крим [ ${ }^{48}$, с. 356]. У монографії «Національні меншини України у XX столітті: Історіографічний нарис» О. Рафальським досліджено провідні тенденції накопичення знань 3 проблематики національних меншин України в XX столітті. Чільне місце в монографії відведено історіографічному аналізу праць опублікованих після проголошення суверенітету і державної незалежності України та виокремлено аспекти міжнаціональних відносин і правового захисту етнічних груп, які фрагментарно були висвітлені в тогочасній історичній та етнологічній літературі [53, с. 46, 47]. 
Регіональні особливості етнополітичних процесів в Україні досліджено в монографії I.T.Зварича «Етнополітика в Україні: регіональний контекст». Зокрема, автором узагальнено досвід державної етнонаціональної політики сучасної Української держави в iï комплексному взаємозв'язку з регіональними особливостями. Розкрито авторське бачення сучасної концепції регіоналізму, іiі ролі та місця у дослідженні міжетнічних відносин. Особливу увагу дослідник зосередив на феномені «нового регіоналізму», який в умовах України - держави з надмірною політизацією регіональних чинників, ніс реальні загрози і виклики іiі національній безпеці [20]. У колективній монографії «Етнополітичні процеси в Україні: регіональні особливості» М. Панчука, В. Свтуха, В. Войналовича, В. Котигоренка, О. Калакури, Н. Кочан, Н. Макаренко, Т. Горбань, О. Ляшенка та Л. Ковач розширюється коло наукових проблем стосовно етнополітичних процесів в Україні та їх регіональної специфіки. Зокрема, авторами проаналізовано результати досліджень історичних умов, політичних, економічних, соціальних, демографічних, культурних, конфесійних та інших аспектів етнополітичої регіоналізації суспільного простору України [17].

У дослідницьких практиках учені оперують модерними поняттями визначеннями термінів «українська етнополітика», «міжцивілізаційні відносини», «етнополітична регіоналізація» та ін., що засвідчило перехід істориків і політологів до нової моделі науки та стратегії взаємовідносин науковець - влада.

У колективному дослідженні співробітників Інституту політичних i етнонаціональних досліджень ім. І.Ф.Кураса НАН України за редакцією Ю.А. Левенеця, В.А. Войналовича, О.П. Дергачова, Г.І. Зеленько, В.О. Котигоренка, О.М. Майбороди, М.I. Михальченка, Ю.І. Шаповала та В.О. Перевезія розкрито вплив російського та європейського цивілізаційних чинників на етнополітичний розвиток України в умовах глобалізації [57].

Привертають увагу публікації вітчизняних учених, присвячені широкому аспекту організаційних засад етнополітичного менеджменту в Україні на основі врахування інтересів усіх представників поліетнічного українського суспільства. У рамках цієї тематики розглянуто функціонування інституцій етнополітичного менеджменту в Україні [14] та його вплив на політичну активність національно-культурних товариств [7, с. 5682]. Серед низки праць виокремлюємо дослідження В. Котигоренка «Становлення державного етнополітичного менеджменту в Україні», де автор указує на необхідність активного залучення національних меншин до ухвалення політичних рішень, в їхніх же інтересах [29]. Подібної думки в своїх розвідках дотримується і Г.Луцишин [41]. У дослідженні В.Колісника «Співвідношення політики і права у процесі формування сучасної державної етнополітики України» указується на непослідовність у реалізації державної етнонаціональної політики та кон'юнктурне ії застосування під час виборчих кампаній в Україні [22, с. 161-173].

Особливості етнокультурного розмаїття сучасної України розглянуто в статті О. Гриценка «Imagining the Community: Perspectives on Ukraine's Ethno-cultural Diversity», 2008 [2].

Етнонаціональний компонент політики ідентичності розкрито в монографічному дослідженні Л.П. Нагорної «Соціокультурна ідентичність: пастки ціннісних розмежувань», де з'ясовується місце і роль соціокультурних ідентичностей (етнічних, територіальних, професійних, гендерних, релігійних та інших), з урахуванням домінуючих ціннісних настанов та поведінкових стереотипів [46].

В.О. Котигоренко, В.А. Войналович, О.Я. Калакура, Л.Л. Ковач, В.В. Коцур, Н.І. Кочан, О.О. Ляшенко, Н.Ю. Макаренко, Ю.О. Ніколаєць, М.І. Панчук, О.В. Позняк, О.О. Рафальський та М.Ю. Рябчук у монографії «Галичина в етнополітичному вимірі» в широкому історичному діапазоні розкривають зв'язок політичного й етнічного у динаміці складу населення Івано-Франківської, Львівської та Тернопільської областей суверенної України, висвітлюють особливості його соціально-професійної стратифікації, мовних, 
культурних та релігійних переваг, характерні риси регіональної ідентичності, електоральної та іншої суспільної поведінки [15].

У монографії В.А. Войналович, Н.І. Кочан «Релігійний чинник етнополітичних процесів у Галичині: повоєнна радянська доба і сучасність» розкриваються особливості взаємодії етнонаціонального, етнонаціонального та релігійного чинників політики в Галичині з радянського періоду до сучасності. Автори відзначають, що цей період відзначаються широким спектром взаємодії релігії та політики, релігійного та етнічного [13].

Велика група наукових досліджень визначає «ракурс бачення» особливостей самобутності окремих етнічних спільнот. Передусім це праці І.Ф. Кураса, Я.О. Калакури, О.І. Котляра, В.А. Василова, Н.П. Шипки [61], В.М. Васильчука [11], В.П. Шквареця, О.М. Іванова, А.В. Скляра, В.О. Котигоренка Л.Л. Ковач та інші дослідників.

Предметом аналізу вітчизняних дослідників стали міжнародні документи у сфері регулювання прав національних меншин України. Так, В. Бородінов у статті «Міжнародний досвід захисту прав національних меншин» акцентував увагу на тому, що в гаазькій та ословській рекомендаціях 1996 і 1998 років викладено зміст прав національних меншин на освіту й мову, а супровідні пояснювальні записки до рекомендацій посилаються на відповідні міжнародні норми [8]. На 95-й сесії Ради Свропи 10 листопада 1994 року Комітет міністрів прийняв Рамкову конвенцію, основною метою якої $є$ ефективний захист прав національних меншин та свобод осіб, які належать до меншин. В історичному контексті Рамкова конвенція стала першим юридично обов'язковим багатостороннім міжнародним документом із захисту національних меншин у всіх сферах суспільного життя. Джерельною базою конвенції були Віденська декларація глав держав та урядів країн-членів Ради Свропи, Свропейська конвенція про захист прав людини й фундаментальних свобод, документи ООН та ОБСЄ, які зобов'язують захищати національні меншини [8].

У вітчизняній історіографії великий масив праць присвячується аналізу державного законодавства із захисту прав національних меншин [8; 50, с. 67; 53, с. 327, 328].

Дослідники дійшли думки, що забезпечуючи національно-культурне відродження українського народу, його традицій, національно-етнографічних особливостей, функціонування української мови як державної в усіх сферах суспільного життя та піклуючись про задоволення національно-культурних, духовних i мовних потреб українців, що проживають за межами країни, згадані правові акти держави гарантували всім народам, національним групам, громадянам, що проживають на iї території, рівні політичні, економічні, соціальні та культурні права [53, с. 326].

Помітний історіографічний пласт в сучасній соціогуманітаристиці утворюють праці, присвячені особливостям договірних відносин між Україною та іншими державами щодо захисту прав національних меншин [53, с. 338].

В. Кулик у статті «Constructing common sense: Language and ethnicity in Ukrainian public discourse» проаналізував впливові презентації питань мови та етнічності в українському політичному та медіа-дискурсі. Дослідивши неоднозначну спадщину, залишену радянським дискурсом та практикою, автор показав, як проект «центристського» пострадянського режиму заради соціальної стабільності переважає над «національно-демократичним» дискурсом, який прагне до радикального перетворення здорового глузду українців відповідно до норм національної держави [3]. Також В. Кулик піднімає мовну проблему в статті «Мовна політика в українських ЗМІ: влада, виробники та споживачі» [4].

У багатоплановому історіографічному масиві праць 3 проблематики національних відносин в Україні доби незалежності з'явилася низка праць присвячених окремим національним меншинам, що проживають на українських теренах. Ці наукові праці розкривають місце і роль поляків, німців, болгар, євреїв, греків та інших національних меншин у період становлення української держави [53, с. 299]. У когорті відомих 
дослідників окресленої проблематики є О. Калакура, В. Тодоров [59, с. 20], А. Василова [10, с. 157 - 162], О. Котляр [32, с. 29 - 33], Е. Тадеєв та А. Бузаров $\left[{ }^{58}\right]$, В. Лукаш [40, с. 8], В. Шкварець [62], О. Іванова [23, с. 301 - 305], Л. Хамула [60, 618 - 622 с.], О. Щерба [64, с. 138 - 143], Л. Стрільчук [56, с. 96 - 102], А. Скляр [55, с. 214 - 220]. Зокрема, О.Я. Калакура [25, 508 с.], Н.О. Зіневич [21, с. 18], В.О. Котигоренко [31, с. 222] досліджують відповідно національні меншини поляків, циганський етнос та кримськотатарських репатріантів.

Помітне місце в сучасному історіографічного дискурсі посідає «русинське питання». У «Висновках Інституту політичних і етнонаціональних досліджень ім. І.Ф. Кураса НАН України щодо «Русинського питання» висловлена думка про унікальність русинського етносу, який активно розвивається в процесі тривалого націєтворення. За даними Всеукраїнського перепису населення кількість осіб, що ідентифікували себе як «русини» становила 32,4 тисячі (про це свідчать результати опитування, на запитання: - «Ким Ви себе вважаєте?» (а) українцем, б) українцем-русином, в) русином). Цю статистику підтверджують і органи державної влади Закарпаття $[12$, с. 134, 135]. Зокрема, вони вказують на те, що в районах Закарпатській області діяли понад 20 громадських організацій («Сойм підкарпатських русинів», «Народна Рада Русинов», «Крайове товариство підкарпатських Русинов», Русинське науково-освітне товариство та ін.); 27 недільних шкіл, де вивчалася русинська мова, література і культура; русинською мовою виходили газети «Подкарпатская Русь», «Підкарпатський Русин» та збірники «Руснацький світ»; розвивали творчість русинських письменників, художників, артистів, проводилися виставки, науково-практичні «круглі столи», конференції. За друкованими виданнями русинською мовою Україна посідала 2 місце в Свропі після Словаччини [12, с. 135].

Науковці дійшли думки, що держава має сприяти розвитку русинського культурноосвітнього руху, але не перетворювати його в рух за збереження субетнічності, штучного створення окремої національності, до чого прагнули деякі діячі так званого «русинофільства», що слугувало причиною розпалювання сепаратизму [12, с. 136].

Оновлювалася проблематика наукових досліджень присвячених етнічній меншині ромів. На думку дослідників, потребують державної уваги, як взаємини «більшості» 3 ромами, так і основні проблеми, з якими стикається цей народ в Україні. На 2001 р. громада ромів налічувала близько 47,6 тис. осіб, з яких майже 14 тис. проживали на Закарпатті та по 4 тис. у Донецькій, Дніпропетровській і Одеській областях. Проте окремі науковці, представники ромської громадськості і деякі посадовці, вважають, що насправді ромів на теренах України значно більше. Так, за розрахунками Інституту мистецтвознавства, фольклористики та етнології НАН України, кількість представників ромського етносу в Україні сягає близько 200 тис. осіб, однак роми часто приховують свою етнічну приналежність [1].

Становище німецької національної меншини розкрито в наукових розвідках Л.М. Коцур, де йдеться про особливості компактного проживання німецької національної меншини на території України, іiі участь у громадсько-політичному житті країни 1990х pp., зокрема, президентських і парламентських виборах, в роботі органів місцевого самоврядування [34]. А у статті дослідниці «Політизація німецької національної меншини України в умовах безпекових викликів у 1990 роках» розкрито причини політизації німецької національної меншини в Україні, виявлено специфіку взаємовідносин між представниками німецької національної меншини і вищими органами влади України наприкінці XX ст. [35, с. 87-92].

Російській національній меншині присвячено публікацію І. Стебельського «Етнічна самоідентифікація в Україні, 1989-2001 роки: чому більше українців та менше росіян?», де автор наголошує на тому, що найбільш готовими до переходу від російської до української ідентичності є члени російсько-українських сімей [5]. Л.М. Коцур у статтях «Тактика посилення російського впливу на етнонаціональну сферу України у другій пол. 1990-х pp.» [36] та «Етнополітична специфіка діяльності Російської Федерації на теренах 
України у 1990-х рр.» [33, с. 132-139] доводить, що наприкінці XXI ст. російська національна меншина України використовувалася російською державою з метою тиску на прийняття важливих внутрішньополітичних рішень вищими органами влади України. Зокрема, етнічні росіяни активно використовувалися Російською Федерацією під час штучного нагнітання істерії навколо «примусової українізації» та кризових ситуацій у Криму і на Донбасі. А чимало народних депутатів, росіян за національністю, лобіювали мовне питання у парламенті з метою надання російській мові статусу другої державної.

Проте, як відзначає фінська журналістка Анна-Лєна Лаурен, «своїм вторгненням в Україну 2014 року Росія досягла протилежного ефекту, переконавши принаймні українців, що їм «русский мир» не потрібний» [38, с. 118-119].

Російсько-українська війна провела криваву межу між обома народами, довела, що Росія проводить проти України етнічну війну на винищення, організовує на українських землях, за висловлюванням Ю. Щербака, зіткнення цивілізацій «диктаторського Сходу» 3 демократичним Заходом, знищує основи української національної ідентичності (мову, культуру, історичну пам'ять) [63, с. 211].

На думку Є. Марчука, Росія давно готувала політичну, військову, інформаційну операцію проти України. До цього слід додати організовану Росією паспортизацію населення Криму, що не робиться експромтом [44, с. 349]. Водночас анексія Росією Криму привернула увагу світових гравців, які зрозуміли, що це проблема не лише України, а й усього світу, бо Росія фактично розірвала Будапештський меморандум і поставила хрест на проблемі ядерної безпеки у світі [44, с. 354].

О. Майборода в одному із інтерв'ю розкриває особливості становища російської національної меншини в Україні, указує на те, що ця проблематика й досі залишається найменше дослідженою [18].

Як бачимо, багатовимірне вивчення російської національної меншини в Україні на часі, враховуючи нові виклики XXI століття, перебіг російсько-української війни та спроби Російської Федерації, за допомогою профінансованих Кремлем політиків, громадських організацій, дестабілізувати політичну ситуацію в нашій країні.

3 огляду на постійне втручання Росії у внутрішні справи України, мінливу суспільно-політичну ситуацію в нашій країні, потребують систематичного і глибокого моніторингу настрої російської громади в Україні, зокрема, стосовно ставлення до питання війни на сході України, анексії Криму, євроінтеграційних перетворень. Проукраїнська частина російської нацменшини відстоює у війні на сході суверенітет і територіальну цілісність Української держави, водночас $є$ й і елементи, що підтримують ідеї «русского мира» та антиукраїнські дії східного сусіда.

Ще в 2010 р., задовго до початку російської агресії проти України, Патріарх РусиУкраїни Філарет відзначав, що під благозвучною вивіскою «русского мира» криється імперська ідея позбавлення України ії державності та незалежності [63, с. 163].

В основу «русского міра», на думку Ю. Щербака, «покладено месіонерську ідеологію російської винятковості («большая российская цивилизация», за словами міністра закордонних справ РФ Лаврова), агресивні плани «захисту співвітчизників» безвідносно від того - чи потребують і просять вони захисту - наявність великих запасів ядерної зброї в арсеналах Росії. «Русскій мір» породив потворну геополітичну химеру так звану Новоросію» [63, с. 163-164].

Соціологічні опитування та історичні дослідницькі практики мають дати відповідні на ці та інші питання, прогнозуючи ймовірні сценарії нових політичних і міжнародних викликів для України в XXI ст.

Окрема історіографічна група об’єднує праці, які розкривають місце і роль, назрілі проблеми кримськотатарського соціуму. Низка праць - «Проблеми інтеграції кримських репатріантів в українське суспільство» [51, 88 с.], «Україна багатоетнічна» [54, с. 156], «Вибори 2002 року у контексті міжнаціональних відносин» [27, с. 55], «Проблеми інтеграції кримських репатріантів в українське суспільство» [52, с. 530], «Соціальна 
адаптація кримськотатарських репатріантів: контекст політичних відносин», «Кримськотатарські репатріанти: проблема соціальної адаптації» В. Котигоренка [31], «Проблема інтеграції кримськотатарського народу в українське суспільство на сторінках регіональної преси» М. Панчука [47], стала важливим етапом наукового осмислення проблем повернення корінного народу на Батьківщину в умовах глобалізації, посилення імперських зазіхань Російської Федерації на суверенітет, територіальну цілісність України.

У багатьох дослідженнях українських науковців указувалися зовнішні чинники, зокрема, вплив Російської Федерації на процес політизації національних меншин в Україні. Уже на початку нового тисячоліття відслідковувався сепаратистський характер автономістських тенденцій у діяльності частини організацій національних меншин, які активно підтримувалися російською стороною [49, с. $130-138 ; 42$, с. 253-265; 48, с. 284300], а також простежувалося використання мовного питання для дестабілізації обстановки в Україні в комплексі з вимогами визнати росіян нарівні з українцями державотворчою нацією, запровадити подвійне громадянство, зберегти спільний інформаційний простір РФ і України, російську освіту та розширити підтримку Української православної церкви МП [45, с. 166-174; 9]. Зокрема, В.Нагірний у статті «Політизація російської етнічності в Україні: спроба організаційного оформлення» указував на те, що саме проголошення росіян України національною меншиною, після розпаду СРСР, стало об'єктивною причиною їх політизації, яка мала ланцюгову реакцію впливу на інші групи меншин. Як відмічає дослідник, важливу роль у цьому сенсі відіграла значна русифікація як українського населення, так і деяких інших груп національних меншин та цілеспрямований зовнішньополітичний курс РФ, що забезпечило можливість експлуатації «російської карти» в політичному житті України, зокрема, у виборчих кампаніях, де постійно піднімалося питання розширення співробітництва з РФ та зміни статусу російської мови в Україні тощо [45, с. 167].

У цьому контексті важливою є монографія авторського колективу IПіЕНД імені І.Ф.Кураса НАН України - «Закарпаття в етнополітичному вимірі» (2008). У ній розкриваються зміст, характер та наслідки урядової політики за різних державних утворень щодо етнічної сфери закарпатського регіону. Особлива увага звертається на сутність та перебіг етнополітичних процесів на Закарпатті у контексті загальних суспільних змін за часів радянського режиму та в умовах незалежної України [19].

Поглиблює розуміння регіональної етнонаціональної специфіки монографія «Донбас в етнополітичному вимірі», де підбито підсумки комплексного дослідження історії і сучасної динаміки етнополітичних процесів на території українського Донбасу. Автори розкрили зв'язок етнічного і політичного в формуванні складу, зайнятості та соціальнопрофесійної стратифікації, мовних, культурних і релігійних орієнтацій, регіональної ідентичності та особливостей суспільної поведінки населення Донбаського регіону України, а також обгрунтували комплекс пропозицій щодо умов і способів реінтеграції Донбасу і його населення в суспільний простір України [16].

В сучасних дослідницьких практиках активно розглядається проблематика політикоправового становища етнічних меншин, їх самоврядної діяльності, повернення депортованих кримських татар та інших народів на етнічні території, міжетнічних та міжнаціональних відносин у сфері культури, релігії, мови, історичної спадщини тощо [6, c. 1].

Утворення і функціонування національно-культурних об'єднань України також була одною із провідних тем сучасного наукового дискурсу, в ході якого запропоновано нові методологічні підходи до узагальнення i систематизації різних форм громадської активності організацій етнічного спрямування та їх місця в інституціональній структурі громадянського суспільства [39, с. 51-60].

Не оминула сучасна українська історіографія i проблеми етнічних протиріч $\mathrm{i}$ конфліктів у країні. Фундаментальною в цьому сенсі $є$ праця В.О. Котигоренка «Етнічні 
протиріччя i конфлікти в сучасній Україні: політологічний концепт». Монографія розкриває природу, зміст та динаміку етнополітичних конфліктів, зумовлених спадщиною комуністичної системи, специфікою розвитку етнодемографічної та етносоціальної структури українського суспільства, особливостями вітчизняної економіки і політики, культури і суспільної свідомості та психології, геополітичних і цивілізаційних викликів сучасності, активізацією етнічних спільнот у демонструванні та обстоюванні своїх інтересів у процесі та після здобуття Україною незалежності [30].

Отже, дослідницькі практики здійснюються переважно в духовно-інтелектуальному контенті нової епохи, яка змінила стиль мислення вчених, методологічні настанови і концепції сучасної історії України. Початок переосмислення і розвідки окресленої наукової проблематики співпадає в часі з перетворенням українського історіографічного дискурсу з другорядної маргінальної структури радянської доби в національну історичну науку зі своїми інституціями, кадрами, впливами європейської соціогуманітаристики.

У наукових працях М. Панчука, В. Котегоринка, О. Майбороди, О. Калакури, М. Кармазіної, Т. Бевз та ін. простежується не лише пізнавальна і практична спрямованість, а й експертна оцінка спрямована на вирішення назрілих в українському соціумі соціально-політичних, соціокультурних проблем XXI століття в царині міжнаціональних відносин.

На сучасному етапі наукових досліджень 3 проблематики національних меншин в Україні, особливо в умовах агресії Російської Федерації, гібридної війни, історична наука остаточно позбувається росієцентричних упереджень, викривлених історичних фактів, гіперболізованих проросійських шовіністичних версій минулого і сучасного українського періоду.

«Водночас додає актуальності досліджуваній проблемі позиція більшості російських істориків, що взялися виправдовувати анексію «Автономної Республіки Крим» історичними фактами і підтримали прокремлівські сепаратистсько-терористичні сили на Донбасі [24, с. 51].

В нинішніх історичних реаліях нового етапу боротьби за утвердження Української держави формується нове «історіографічне покоління» 3 власними «ідейно-ціннісними та соціально-генетичними вимірами» [26, с. 33] і водночас характерною рисою сучасної моделі відносин між «істориками і владою в Україні стала безпосередня участь учених у процесах формування національної ідентичності за допомогою історіографічних модулів національної історії» [26, с. 53].

В сучасних умовах, коли українська еліта «зацікавлена в створенні респектабельного національного наративу» [26, с. 53], проблематика етнополітичних процесів в Україні 1990-х - 2000-х рр. залишається актуальною і далеко невичерпаною як під кутом зору нових впливів глобалізованого світу, «гібридної війни», так і триваючої заміни «культури партійності» (за І. Колесник) новою культурою мислення.

До актуальних питань сучасних дослідницьких практик в царині національних відносин слід віднести «історичний тягар» нерозв'язаних проблем кримськотатарського народу і окупацію Росією півострова; російська національна меншина в Україні в умовах «гібридної війни», загарбання Криму і частини Донецької і Луганської областей; російський слід в «угорському питанні» на Закарпатті в умовах електоральних i фінансово-енергетичних залежностей правлячих еліт Угорщини від Росії; національні меншини і підривна діяльність російських спецслужб на Півдні України; питання державної мови, освітня реформа і реалізація соціальних, політичних, соціокультурних потреб національних меншин; залучення національних меншин до активної державотворчої діяльності на основі європейських ціннісних орієнтирів демократії, верховенства права. 


\section{ДЖЕРЕЛА ТА ЛІТЕРАТУРА}

1. «Форум націй». Навіщо «бити» етнічну карту? Поки кандидати в президенти не бачать проблем у міжнаціональній сфері, приводи для штучних спекуляцій знаходять політтехнологи. Жовтень 2004. № 10 (29). URL: http://www.forumn.kiev.ua/Forum34.htm.

2. Hrytsenko O. Imagining the Community: Perspectives on Ukraine's Ethno-cultural Diversity. Nationalities Papers. Volume 36. 2008. Issue 2. URL: https://www.tandfonline.com/doi/full/10.1080/00905990801934280 (Дата звернення: 19.07.2018).

3. Kulyk V. Constructing common sense: Language and ethnicity in Ukrainian public discourse. Ethnic and Racial Studies. Volume 29. 2006. Issue 2. URL: https://www.tandfonline.com/doi/full/10.1080/01419870500465512 (Дата звернення: 20.07.2018).

4. Kulyk V. Language Policy in the Ukrainian Media: Authorities, Producers and Consumers. Europe-Asia Studies. Volume 65. 2013. Issue 7. URL: https://www.tandfonline.com/doi/full/10.1080/09668136.2013.824138 (Дата звернення: 23.07.2018).

5. Stebelsky I. Ethnic Self-Identification in Ukraine, 1989-2001: Why More Ukrainians and Fewer Russians? Canadian Slavonic Papers. Volume 51. 2009. Issue 1. URL: https://www.tandfonline.com/doi/abs/10.1080/00085006.2009.11092603 (Дата звернення: 17.07.2018).

6. Арсенян М. Вірменська спадщина Кілії. Вірменський вісник №1-3(51). Информационно-аналитическое издание общественной организации «Союз Армян Украины». Січень - березень. 2011. 32 с.

7. Барановська Н. В. Національно-культурні товариства у життєвому просторі держави. Життєвий простір України: політичний та гуманітарний виміри (1991 -2010рр.): збірник наукових статей. Київ. 2012. С. 56-82.

8. Бородінов В. Міжнародний досвід захисту прав національних меншин. URL: www.viche.info/journal/2705/]/.

9. Бурдяк В. Розвиток державної етнонаціональної політики в сучасній Україні. Наукові записки Інституту політичних і етнонаціональних досліджень ім. І.Ф. Кураса НАН України. Вип. 40. Київ. 2008. 392 с.

10. Василова В.А. Становище національних меншин та етнополітичний аспект українсько-румунських відносин у 90-х pp. XX ст. Наук. вісник Волинського національного університету імені Л. Українки. 2010. С. 157-162.

11. Васильчук В.М. Громадське і духовне життя німецької спільноти в Україні. URL: http://archive.nbuv.gov.ua/portal/soc_gum/Npifznu/2006_20/20/vasylchuk.pdf.

12. Висновок Інституту політичних і етнонціональних дослідженім. І.Ф. Кураса НАН України щодо «Русинського питання». Вісник держкомнацрелігій України. Київ. 2008. №1. С. 134-136.

13. Войналович В.А., Кочан Н.I. Релігійний чинник етнополітичних процесів у Галичині: повоєнна радянська доба і сучасність. Київ: ІПіЕНД ім. І.Ф. Кураса НАН України. 2018. 408 с.

14. Гаврада Н. Інституційна складова реалізації державної етнополітики: центральний та регіональний виміри. URL: http://buktolerance.com.ua/?p=2187 (11.11.2014).

15. Галичина в етнополітичному вимірі. Авт. кл.: В.О. Котигоренко (керівник), В.А. Войналович, О.Я. Калакура, Л.Л. Ковач, В.В. Коцур, Н.I. Кочан, О.О. Ляшенко, Н.Ю. Макаренко, Ю.О. Нікалаєць, М.І. Панчук, О.В. Позняк, О.О. Рафальський, М.Ю. Рябчук. К иїв. ІПіЕНД. 2017. 840 с.

16. Донбас в етнополітичному вимірі. Київ. ІПіЕНД імені І.Ф. Кураса НАН України. 2014. 584 c. 
17. Етнополітичні процеси в Україні: регіональні особливості. [Монографія]. Київ. Інститут політичних та етнонаціональних досліджень ім. І.Ф.Кураса НАН України. 2011. $396 \mathrm{c.}$

18. Загадки українських росіян: найбільша національна меншина найменше досліджена. Громадське радіо. 05.11.2014: URL: https://hromadskeradio.org/ru/programs/hromadyany-ukrayiny/zagadky-ukrayinskyh-rosiyannaybilsha-nacionalna-menshyna-naymenshe-doslidzhena (Дата звернення: 26.07.2018).

19. Закарпаття в етнополітичному вимірі. Київ. ІПіЕНД імені І.Ф.Кураса НАН України. 2008. 682 с.

20. Зварич I.Т. «Етнополітика в Україні: регіональний контекст». Київ. Дельта. 2009. $320 \mathrm{c}$.

21. Зіневич Н.О. Циганський етнос в Україні (історіографія та джерела). Автореф. дис. ... канд. іст. наук: 07.00.06; НАН України. Ін-т укр. археографії та джерелознавства ім. М.С. Грушевського. Київ. 2005. 18 с.

22. Зінич В. Розселення й облаштування депортованих національних меншин важлива складова етнонаціональної політики держави. Наукові записки. Курасівські читання-2005. Серія «Політологія і етнологія». Вип. 30, кн. 1 Київ. ІПіЕНД. 2006. С. 161 173.

23. Іванова О. М. Мовно-освітні проблеми російської меншини в Україні та української меншини в Російській Федерації (90-ті роки XX століття). Наук. праці іст. фту Запорізького національного університету. Вип. XXVIII. 2010. С. 301-305.

24. Калакура «Синдром комунізації» істориків і його живучість у пострадянській українській історіографії. Історик і влада. Колективна монографія. Відповід. Ред. В. Смолій, творчий керівник проекту І. Колесник. Київ: Інститут історії НАН України. 2016. С. 57.

25. Калакура О.Я. Поляки в етнополітичних процесах на землях України у ХX столітті. Київ. Знання України. 2007. 508 с.

26. Колесник I. Український історик та Влада: точка неповернення. Історик і влада. C. $33 ; 53$.

27. Конгрес національних громад України. Вибори 2002 у контексті міжнаціональних відносин. Матеріали моніторингу. Вип. 1. Київ. 2002. С. 54-55.

28. Коршук P.M. Моделі етнополітики. URL: http://archive.nbuv.gov.ua/portal/Soc_Gum/Gileya/2010_40/Gileya40/P12_doc.pdf.

29. Котигоренко В. Становлення державного етнополітичного менеджменту в Україні. URL: tp://www.politik.org.ua/vid/magcontent.php3?m=1\&n=34\&c=600 (Дата звернення: 11.11.2014).

30. Котигоренко В.О. Етнічні протиріччя і конфлікти в сучасній Україні: політологічний концепт. Київ. Світогляд. 2004. 722 с.

31. Котигоренко В.О. Кримськотатарські репатріанти: проблема соціальної адаптації. Київ. Світогляд. 2005. 222 с.

32. Котляр О. I. Правове врегулювання захисту прав національних меншин Німеччини. Журн. Наука і практика. №2 (37). 2012. С. 29-33.

33. Коцур Л. Етнополітична специфіка діяльності Російської Федерації на теренах України у 1990-х рр. Наукові записки з української історії: зб. наукових статей. №36. Переяслав-Хмельницький: Лукашевич O.M., 2015. C. 132-139. URL: https://scholar.google.com.ua/citations?user=XzTrv0YAAAAJ\&hl=ru\#d=gs_md_cita$\mathrm{d} \& \mathrm{p}=\& \mathrm{u}=\% 2 \mathrm{Fcitations} \% 3 \mathrm{Fview}$ _op\%3Dview_citation\%26hl\%3Dru\%26user\%3DXzTrv0YAA AAJ\%26citation_for_view\%3DXzTrv0YAAAAJ\%3AW7OEmFMy1HYC\%26tzom\%3D-180 (Дата звернення: 26.07.2018).

34. Коцур Л.М. Національні меншини України в етнополітичних процесах наприкінці 1980-х - у 1990-х рр.: автореферат дисертації на здобуття наукового ступеня кандидата історичних наук. Міністерство освіти і науки України; Державний вищий 
навчальний заклад "Переяслав-Хмельницький державний педагогічний університет імені Г. Сковороди. 2015.2620 URL: http://176.105.99.186:8081/xmlui/bitstream/handle/8989898989/1336/\%D0\%9A\%D0\%BE\%D1 $\% 86 \%$ D1\%83\%D1\%80\%20\%D0\%9B.\%20\%D0\%9C.(211\%D0\%94\%D0\%B8\%D1\%81).pdf?se quence $=1 \&$ is Allowed=y (Дата звернення: 26.07.2018).

35. Коцур Л.М. Політизація німецької національної меншини України в умовах безпекових викликів у 1990 роках. Науковий журнал «Молодий вчений», № 9 (49.1). Херсон. $2017 . \quad$ C. 87-92. URL: https://scholar.google.com.ua/citations?user=XzTrv0YAAAAJ\&hl=ru\#d=gs_md_cita$\mathrm{d} \& \mathrm{p}=\& \mathrm{u}=\% 2 \mathrm{Fcitations} \% 3 \mathrm{Fview}$ _op\%3Dview_citation\%26hl\%3Dru\%26user\%3DXzTrv0YAA AAJ\%26citation_for_view\%3DXzTrv0YAAAAJ\%3A9ZIFYXVOiuMC\%26tzom\%3D-180 (Дата звернення: 26.07.2018).

36. Коцур Л.М. Тактика посилення російського впливу на етнонаціональну сферу України у другій пол. 1990-х рр. Наукові записки з української історії: зб. наук. статей, №42. Переяслав-Хмельницький (Київ. обл.) : Домбровська Я.M. 2017. 144 с. URL: https://scholar.google.com.ua/citations?user=XzTrv0YAAAAJ\&hl=ru\#d=gs_md_cita-

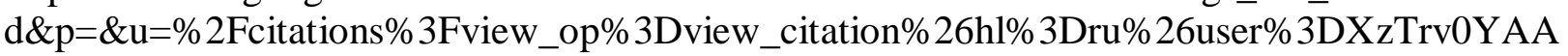
AAJ\%26citation_for_view\%3DXzTrv0YAAAAJ\%3AmVmsd5A6BfQC\%26tzom\%3D-180 (Дата звернення: 26.07.2018).

37. Курас І.Ф. Етнополітика: Історія та сучасність. Статті, виступи, інтерв’ю 90-х років. Київ. ІПіЕНД, 1999. 656 с.

38. Лаурен Анна-Лєна, Луденіус Петер. Україна на межі. Львів. ЛА «Піраміда». 2016. С. $118-119$.

39. Лойко Л. Типологічне позиціювання національних організацій в інституціональній структурі громадянського суспільства. Політичний менеджмент №5. 2005. С. 51-60.

40. Лукаш В.Я. Реалії та перспективи політичної та економічної стабілізації в Криму.

http://archive.nbuv.gov.ua/portal/Soc_Gum/Gileya/2012_63/Gileya63/P22_doc.pdf - 8 c.

41. Луцишин Г. Національні меншини та політичний процес в Україні. URL: http://www.westukr.itgo.com/Lucyshyn.html (Дата звернення: 31.052014).

42. Ляшенко О. До питання про перспективи адміністративно-територіальної реформи в Україні: досвід автономізації Криму та Закарпаття. Наукові записки. Збірник. Серія «Політологія і етнологія». Вип. 29. Київ. Інституту політичних і етнонаціональних досліджень ім. І.Ф. Кураса НАН України. 2006. С. 253-265.

43. Майборода О. Хоч і про головне, але пісня стара. Конгрес національних громад України. 2006. Форум націй. URL: http://www.forumn.kiev.ua/Forum34.htm

44. Марчук Є.К. На шляху до НАТО. Київ-Париж-Дакар. 2016. С. 349-354.

45. Нагірний В. Політизація російської етнічності в Україні: спроба організаційного оформлення. Наукові записки. Збірник. Серія «Політологія і етнологія». Вип. 14. Київ. ІПіЕНД. 2000. С. 166-174.

46. Нагорна Л.П. Соціокультурна ідентичність: пастки ціннісних розмежувань. Київ. ІПіЕНД ім. І.Ф. Кураса НАН України. 2011. 272 с.

47. Наукові записки Інституту політичних і етнонаціональних досліджень НАН України. Курасівські читання-2005. Сер. «Політологія і етнологія»; Вип. 30, кн. 1. Київ. ІПІЕНД. 2006. 391 с.

48. Панчук М., Войналович В., Геник М., Калакура О., Котигоренко В. та ін. Національні меншини України у XX столітті: політико-правовий аспект. Київ. IПЕІНД. 2000. $356 \mathrm{c}$.

49. Панчук М., Рафальський О. Етнополітика України: досвід десятиліття. Українське державотворення: уроки, проблеми, перспективи: Матеріали науковопрактичної конференції. Львів: ЛФ УАДУ, 2001. Ч.2. С. 130-138. 
50. Пилипенко T.І. Стан імплементації положень Рамкової Конвенції Ради Свропи про захист прав національних меншин в Україні. Вісник держкомнацрелігій України. Київ. 2008. №1. С. 65-105.

51. Проблеми інтеграції кримських репатріантів в українське суспільство. Збірник матеріалів семінару Київського проекту інституту Кеннана та Інституту політичних i етнонаціональних досліджень НАН України, 13-14 травня 2004 р. Київ. Стилос. 2004. 88 с.

52. Проблеми інтеграції кримських репатріантів в українське суспільство. Матеріали Всеукраїнської науково-практичної конференції. м. Київ, 13-14 травня 2004 р. Київ. Світогляд. 2004. 530 с.

53. Рафальський О.О. Національні меншини України у XX столітті: Історіографічний нарис. Київ. Полюс, 2000. 447 с.

54. Сагон. О.Н., Пилипенко Т.I. (упоряд.) Україна багатоетнічна. Держ. ком. України у справах національностей та релігій. Київ. Світ знань. 2008. 156 с.

55. Скляр А.В. Питання забезпечення прав національних меншин як приклад асиметричності взаємин у двосторонніх відносинах між Україною та Румунією. Наук. Вісн. Дипломатичної академії України. Вип. 15. 2009. С. 214-220.

56. Стрільчук Л.В. Питання етнічних меншин у відносинах між Україною та Польщею. Історичні студії. Волинський нац. Універ-т ім. Л. Українки. 2009. С. 96-102.

57. Сучасна українська політика. Аналітичні доповіді Інституту політичних i етнонаціональних досліджень ім. І.Ф.Кураса НАН України. Київ. ІПіЕНД ім. І.Ф.Кураса НАН України. 2009. 448 с.

58. Тадєєв Е., Бузаров А. Осетини як національна меншина України. URL: http://www.viche.info/journal/3015/.

59. Тодоров В. І. Болгари українського Придунав'я: етнографічна характеристика. Автореф. 2009. 20 c.

60. Хамула Л. Стереотипи польсько-українських відносин у польській пресі 90-х pp. XX ст. - початку XXI ст. Україна культурна спадщина, національна свідомість, державність. №17. 2008. С. 618-622.

61. Шипка Н.П. Угорська національна меншина у виборчих процесах незалежної України. URL: http://archive.nbuv.gov.ua/portal/Soc_Gum/Npchdu/Politology/2008_66/6622.pdf.

62. Шкварець В. Німці південного регіону сучасної української держави. URL: www.nbuv.gov.uaportalSoc_GumNvmduIst...3...shkvarets.pdf.

63. Щарбак Ю. Україна в епіцентрі світового шторму: оцінки, прогнози, коментарі. Київ. Ярославів Вал. 2017. С. 163-164; 211.

64. Щерба О. Кримськотатарська спільнота як суб'єкт політики: теоретичний аспект. Українська національна ідея: реалії та перспективи розвитку. Вип. 24. 2012. С.138143.

\section{REFERENCES}

1. «Forum natsii». Navishcho «byty» etnichnu kartu? Poky kandydaty v prezydenty ne bachat problem u mizhnatsionalnii sferi, pryvody dlia shtuchnykh spekuliatsii znakhodiat polittekhnolohy [The "Forum of Nations". Why "beat" an ethnic card? Until presidential candidates see problems in the international sphere, political technocrats find the cause for artificial speculation]. Zhovten [October]. 2004. 10 (29). URL: http://www.forumn.kiev.ua/Forum34.htm) [in Ukrainian].

2. Hrytsenko, O. (2008). Imagining the Community: Perspectives on Ukraines Ethnocultural Diversity [Imagining the Community: Perspectives on Ukraine's Ethno-Cultural Diversity]. Nationalities Papers [Nationalities Papers]. 36. 2. URL: https://www.tandfonline.com/doi/full/10.1080/00905990801934280 [in English].

3. Kulyk, V. (2006). Constructing common sense: Language and ethnicity in Ukrainian public discourse [Constructing Common Sense: Language and Ethnicity in Ukrainian Public 
Discourse]. Ethnic and Racial Studies [Ethnic and Racial Studies]. 29. 2. URL: https://www.tandfonline.com/doi/full/10.1080/01419870500465512 [in English].

4. Kulyk, V. (2013). Language Policy in the Ukrainian Media: Authorities, Producers and Consumers [Language Policy in the Ukrainian Media: Authorities, Producers and Consumers]. $\begin{array}{llllll}\text { Europe-Asia Studies } & \text { [Europe-Asia } & \text { Studies]. } & 65 . & 7 . & \text { URL: }\end{array}$ https://www.tandfonline.com/doi/full/10.1080/09668136.2013.824138 [in English].

5. Stebelsky, I. (2009). elf-Identification in Ukraine, 1989-2001: Why More Ukrainians and Fewer Russians? [Ethnic Self-Identification in Ukraine, 1989-2001: Why More Ukrainians and Fewer Russians?] Canadian Slavonic Papers [Canadian Slavonic Papers]. 51. 1. URL: https://www.tandfonline.com/doi/abs/10.1080/00085006.2009.11092603 [in English].

6. Arsenian, M. (2011). Virmenska spadshchyna Kilii [Armenian Heritage of Kylia]. Virmenskyi visnyk [Armenian Bulletin]. 1-3(51). Ynformatsyonno-analytycheskoe yzdanye obshchestvennoi orhanyzatsyy «Soiuz Armian Ukraynu» [Information and analytical publication of the public organization "Union of Armenians of Ukraine"]. Sichen - berezen [January March]. 32 [in Ukrainian].

7. Baranovska, N.V. (2012). Natsionalno-kulturni tovarystva u zhyttievomu prostori derzhavy [National-cultural societies in the living space of the state]. Zhyttievyi prostir Ukrainy: politychnyi ta humanitarnyi vymiry (1991 -2010 rr.): zbirnyk naukovykh statei [The Living Space of Ukraine: Political and Humanitarian Dimensions (1991-2010): Collection of Scientific Articles]. Kyiv. 56-82 [in Ukrainian].

8. Borodinov, V. Mizhnarodnyi dosvid zakhystu prav natsionalnykh menshyn [International experience in protecting the rights of national minorities]. URL: www.viche.info/journal/2705/]/ [in Ukrainian].

9. Burdiak, V. (2008). Rozvytok derzhavnoi etnonatsionalnoi polityky v suchasnii Ukraini [Development of state ethno-national policy in modern Ukraine]. Naukovi zapysky Instytutu politychnykh i etnonatsionalnykh doslidzhen im. I.F. Kurasa NAN Ukrainy [Scientific Notes of the Institute of Political and Ethnic Studies IF National Academy of Sciences of Ukraine]. 40. Kyiv [in Ukrainian].

10. Vasylova, V.A. (2010). Stanovyshche natsionalnykh menshyn ta etnopolitychnyi aspekt ukrainsko-rumunskykh vidnosyn u 90-kh rr. XX st. [The situation of national minorities and the ethno-political aspect of Ukrainian-Romanian relations in the 1990s.]. Nauk. visnyk Volynskoho natsionalnoho universytetu imeni L. Ukrainky [Science. Bulletin of Volyn National University named after L. Ukrainka]. 157-162 [in Ukrainian].

11. Vasylchuk, V.M. (2006). Hromadske i dukhovne zhyttia nimetskoi spilnoty v Ukraini [Public and spiritual life of the German community in Ukraine]. URL: http://archive.nbuv.gov.ua/portal/soc_gum/Npifznu/2006_20/20/vasylchuk.pdf [in Ukrainian].

12. (2008). Vysnovok Instytutu politychnykh i etnontsionalnykh doslidzhenim [Conclusion of the Institute of Political and Ethnic Studies]. I.F. Kurasa NAN Ukrainy shchodo «Rusynskoho pytannia» [IF National Academy of Sciences of Ukraine on the Rusyn Question]. Visnyk derzhkomnatsrelihii Ukrainy [Bulletin of the State Committee for National Religions of Ukraine]. Kyiv. 1. 134-136 [in Ukrainian].

13. Voinalovych, V.A. \& Kochan, N.I. (2018). Relihiinyi chynnyk etnopolitychnykh protsesiv u Halychyni: povoienna radianska doba $\mathrm{i}$ suchasnist [The religious factor of ethnopolitical processes in Galicia: the post-war Soviet era and modernity]. Kyiv: IPiEND im. I.F. Kurasa NAN Ukrainy [IPIEND them. IF National Academy of Sciences of Ukraine] [in Ukrainian].

14. Havrada, N. Instytutsiina skladova realizatsii derzhavnoi etnopolityky: tsentralnyi ta rehionalnyi vymiry [Institutional component of state ethnopolitics realization: central and regional dimensions]. URL: http://buktolerance.com.ua/?p=2187 [in Ukrainian].

15. (2017). Halychyna $\mathrm{v}$ etnopolitychnomu vymiri [Galicia in the Ethnopolitical Dimension]. (Ed.) Avt. kl.: V.O. Kotyhorenko (Head) (kerivnyk) , V.A. Voinalovych, O.Ya. Kalakura, L.L. Kovach, V.V. Kotsur, N.I. Kochan, O.O. Liashenko, N.Yu. Makarenko, 
Yu.O. Nikalaiets, M.I. Panchuk, O.V. Pozniak, O.O. Rafalskyi, M.Yu. Riabchuk. Kyiv. IPiEND [in Ukrainian].

16. (2014). Donbas $\mathrm{v}$ etnopolitychnomu vymiri [Donbass in the Ethnopolitical Dimension]. Kyiv. IPiEND imeni I.F. Kurasa NAN Ukrainy [IFIEN IPEND National Academy of Sciences of Ukraine] [in Ukrainian].

17. (2011). Etnopolitychni protsesy v Ukraini: rehionalni osoblyvosti [Ethnopolitical Processes in Ukraine: Regional Features]. Monohrafiia [Monograph]. Kyiv. Instytut politychnykh ta etnonatsionalnykh doslidzhen im. I.F.Kurasa NAN Ukrainy [Institute of Political and Ethnic Studies IF Kuras of the NAS of Ukraine] [in Ukrainian].

18. (2014). Zahadky ukrainskykh rosiian: naibilsha natsionalna menshyna naimenshe doslidzhena [Mysteries of Ukrainian Russians: the largest national minority is the least explored]. Hromadske radio [Public radio]. 05.11.2014: URL: https://hromadskeradio.org/ru/programs/hromadyany-ukrayiny/zagadky-ukrayinskyh-rosiyannaybilsha-nacionalna-menshyna-naymenshe-doslidzhena [in Ukrainian].

19. (2008). Zakarpattia $\mathrm{v}$ etnopolitychnomu vymiri [Transcarpathia in the Ethnopolitical Dimension]. Kyiv. IPiEND imeni I.F.Kurasa NAN Ukrainy [IF Kuras IPIEND of NAS of Ukraine] [in Ukrainian].

20. Zvarych, I.T. (2009). «Etnopolityka v Ukraini: rehionalnyi kontekst» [Ethnopolitics in Ukraine: Regional Context]. Kyiv. Delta [Delta] [in Ukrainian].

21. Zinevych, N.O. (2005). Tsyhanskyi etnos v Ukraini (istoriohrafiia ta dzherela) [Gypsy Ethnicity in Ukraine (historiography and sources)]. Avtoref. dys. ... kand. ist. nauk: 07.00.06 [Author's abstract diss. ... Cand. ist. Sciences: 07.00.06]; NAN Ukrainy. In-t ukr. arkheohrafii ta dzhereloznavstva im. M.S. Hrushevskoho [NAS of Ukraine. Inst. archeography and source studies. MS Hrushevsky]. Kyiv [in Ukrainian].

22. Zinych, V. (2006). Rozselennia y oblashtuvannia deportovanykh natsionalnykh menshyn - vazhlyva skladova etnonatsionalnoi polityky derzhavy [Resettlement and deportation of deported national minorities is an important component of the state's ethno-national policy]. Naukovi zapysky. Kurasivski chytannia-2005. Seriia «Politolohiia i etnolohiia» [Proceedings. Kurasov readings-2005. Political Science and Ethnology Series]. 30. 1 Kyiv. IPiEND. 161-173 [in Ukrainian].

23. Ivanova, O.M. (2010). Movno-osvitni problemy rosiiskoi menshyny $\mathrm{v}$ Ukraini ta ukrainskoi menshyny v Rosiiskii Federatsii (90-ti roky XX stolittia) [Linguistic and educational problems of the Russian minority in Ukraine and the Ukrainian minority in the Russian Federation (90-ies of XX century)]. Nauk. pratsi ist.f-tu Zaporizkoho natsionalnoho universytetu [Science. the works of the East. Zaporizhzhya National University]. XXVIII. 301-305 [in Ukrainian].

24. Kalakura (2016). «Syndrom komunizatsii» istorykiv i yoho zhyvuchist u postradianskii ukrainskii istoriohrafii [The Calacura "Syndrome of Communication" by historians and its survivability in post-Soviet Ukrainian historiography]. Istoryk $i$ vlada [Historian and power]. Kolektyvna monohrafiia [Collective monograph]. Vidpovid. Red. V. Smolii, tvorchyi kerivnyk proektu I. Kolesnyk [The answer is. Ed. V. S moly, creative director of the project I. Kolesnik]. Kyiv: Instytut istorii NAN Ukrainy [Institute of History of NAS of Ukraine] [in Ukrainian].

25. Kalakura, O.Ya. (2007). Poliaky v etnopolitychnykh protsesakh na zemliakh Ukrainy $\mathrm{u}$ XX stolitti [Poles in Ethnopolitical Processes on the Lands of Ukraine in the Twentieth Century]. Kyiv. Znannia Ukrainy [Knowledge of Ukraine] [in Ukrainian].

26. Kolesnyk, I. Ukrainskyi istoryk ta Vlada: tochka nepovernennia [The Ukrainian historian and Vlad: the point of no return]. Istoryk $i$ vlada [Historian and power]. 33; 53 [in Ukrainian].

27. (2002). Konhres natsionalnykh hromad Ukrainy. Vybory 2002 u konteksti mizhnatsionalnykh vidnosyn [Congress of National Communities of Ukraine. Election 2002 in 
the context of international relations]. Materialy monitorynhu [Monitoring materials]. Kyiv. 1. 54-55 [in Ukrainian].

28. Korshuk, R.M. (2010). Modeli etnopolityky [Models of Ethnopolitics]. URL: http://archive.nbuv.gov.ua/portal/Soc_Gum/Gileya/2010_40/Gileya40/P12_doc.pdf [in Ukrainian].

29. Kotyhorenko, V. Stanovlennia derzhavnoho etnopolitychnoho menedzhmentu v Ukraini [Formation of state ethno-political management in Ukraine]. URL: tp://www.politik.org.ua/vid/magcontent.php3?m=1\&n=34\&c=600 [in Ukrainian].

30. Kotyhorenko, V.O. (2004). Etnichni protyrichchia i konflikty v suchasnii Ukraini: politolohichnyi kontsept [Ethnic Contradictions and Conflicts in Modern Ukraine: A Political Science Concept]. Kyiv. Svitohliad [Outlook] [in Ukrainian].

31. Kotyhorenko, V.O. (2005). Krymskotatarski repatrianty: problema sotsialnoi adaptatsii [Crimean Tatar repatriates: the problem of social adaptation]. Kyiv. Svitohliad [Outlook] [in Ukrainian].

32. Kotliar, O.I. (2012). Pravove vrehuliuvannia zakhystu prav natsionalnykh menshyn Nimechchyny [Legal regulation of the protection of the rights of national minorities in Germany]. Zhurn. Nauka i praktyka [Journal. Science and practice]. 2 (37). 29-33 [in Ukrainian].

33. Kotsur, L. (2015). Etnopolitychna spetsyfika diialnosti Rosiiskoi Federatsii na terenakh Ukrainy u 1990-kh rr. [Ethnopolitical specifics of the Russian Federation's activity in the territory of Ukraine in the 1990s]. Naukovi zapysky z ukrainskoi istorii : zb. naukovykh statei [Scientific Notes on Ukrainian History: Coll. scientific articles]. 36. Pereiaslav-Khmelnytskyi: Lukashevych O.M. 132-139.

URL:

https://scholar.google.com.ua/citations?user=XzTrv0YAAAAJ\&hl=ru\#d=gs_md_cita$\mathrm{d} \& \mathrm{p}=\& \mathrm{u}=\% 2 \mathrm{Fcitations} \% 3 \mathrm{Fview}=\mathrm{op} \% 3 \mathrm{Dview}$ _citation\%26hl\%3Dru\%26user\%3DXzTrv0YAA AAJ\%26citation_for_view\%3DXzTrv0YAAAAJ\%3AW7OEmFMy1HYC\%26tzom\%3D-180 [in Ukrainian].

34. Kotsur, L.M. (2015). Natsionalni menshyny Ukrainy v etnopolitychnykh protsesakh naprykintsi 1980-kh - u 1990-kh rr. [National minorities of Ukraine in ethnopolitical processes in the late 1980s - 1990s]. Avtoref. dis. ... k. i. n. [Dissertation author's abstract for the candidate of historical sciences degree]. Ministerstvo osvity $i$ nauky Ukrainy; Derzhavnyi vyshchyi navchalnyi zaklad "Pereiaslav-Khmelnytskyi derzhavnyi pedahohichnyi universytet imeni H. Skovorody [Ministry of Education and Science of Ukraine; Pereyaslav-Khmelnitsky State Pedagogical University named after G. Skovoroda]. 26. URL: http://176.105.99.186:8081/xmlui/bitstream/handle/8989898989/1336/\%D0\%9A\%D0\%BE\%D1 $\% 86 \%$ D1\%83\%D1\%80\%20\%D0\%9B.\%20\%D0\%9C.(211\%D0\%94\%D0\%B8\%D1\%81).pdf?se quence $=1 \&$ is Allowed $=y$ [in Ukrainian].

35. Kotsur, L.M. (2017). Polityzatsiia nimetskoi natsionalnoi menshyny Ukrainy v umovakh bezpekovykh vyklykiv u 1990 rokakh [The politicization of the German national minority of Ukraine in the face of security challenges in 1990]. Naukovyi zhurnal "Molodyi vchenyi» [Young Scientist Scientific Journal]. 9 (49.1). Kherson. 87-92. URL: https://scholar.google.com.ua/citations?user=XzTrv0YAAAAJ\&hl=ru\#d=gs_md_cita$\mathrm{d} \& \mathrm{p}=\& \mathrm{u}=\% 2$ Fcitations\%3Fview_op\%3Dview_citation\%26hl\%3Dru\%26user\%3DXzTrv0YAA AAJ\%26citation_for_view\%3DXzTrv0YAAAAJ\%3A9ZIFYXVOiuMC\%26tzom\%3D-180 [in Ukrainian].

36. Kotsur, L.M. (2017). Taktyka posylennia rosiiskoho vplyvu na etnonatsionalnu sferu Ukrainy u druhii pol. 1990-kh rr. [Tactics of strengthening Russian influence on the ethnonational sphere of Ukraine in the second gender. 1990s]. Naukovi zapysky z ukrainskoi istorii: zb. nauk. statei [Scientific Notes on Ukrainian History: Coll. of sciences. Articles]. 42. Pereiaslav-Khmelnytskyi (Kyiv. obl.) : Dombrovska Ya.M. 144. URL: https://scholar.google.com.ua/citations?user=XzTrv0YAAAAJ\&hl=ru\#d=gs_md_cita$\mathrm{d} \& \mathrm{p}=\& \mathrm{u}=\% 2 \mathrm{Fcitations} \% 3 \mathrm{Fview}$ _op\%3Dview_citation\%26hl\%3Dru\%26user\%3DXzTrv0YAA 
AAJ\%26citation_for_view\%3DXzTrv0YAAAAJ\%3AmVmsd5A6BfQC\%26tzom\%3D-180 [in Ukrainian].

37. Kuras, I.F. (1999). Etnopolityka: Istoriia ta suchasnist [Ethnopolitics: History and Modernity]. Statti, vystupy, interv'iu 90-kh rokiv [90s articles, speeches, interviews]. Kyiv. IPiEND [in Ukrainian].

38. Lauren, Anna-Liena \& Ludenius, Peter (2016). Ukraina na mezhi [Ukraine on the border]. Lviv. LA «Piramida» [LA "Pyramid"]. 118-119 [in Ukrainian].

39. Loiko, L. (2005). Typolohichne pozytsiiuvannia natsionalnykh orhanizatsii $\mathrm{v}$ instytutsionalnii strukturi hromadianskoho suspilstva [Typological positioning of national organizations in the institutional structure of civil society]. Politychnyi menedzhment [Political Management]. 5. 51-60 [in Ukrainian].

40. Lukash, V.Ya. Realii ta perspektyvy politychnoi ta ekonomichnoi stabilizatsii v Krymu [Realities and prospects of political and economic stabilization in Crimea]. URL: http://archive.nbuv.gov.ua/portal/Soc_Gum/Gileya/2012_63/Gileya63/P22_doc.pdf - 8 [in Ukrainian].

41. Lutsyshyn, H. Natsionalni menshyny ta politychnyi protses $\mathrm{v}$ Ukraini [National minorities and the political process in Ukraine]. URL: http://www.westukr.itgo.com/Lucyshyn.html [in Ukrainian].

42. Liashenko, O. (2006). Do pytannia pro perspektyvy administratyvno-terytorialnoi reformy v Ukraini: dosvid avtonomizatsii Krymu ta Zakarpattia [To the question of prospects of administrative-territorial reform in Ukraine: experience of autonomy of Crimea and Transcarpathia]. Naukovi zapysky. Zbirnyk. Seriia «Politolohiia i etnolohiia» [Proceedings. Collection. Political Science and Ethnology Series]. Kyiv. Instytutu politychnykh $i$ etnonatsionalnykh doslidzhen im. I.F. Kurasa NAN Ukrainy [Institute of Political and Ethnic Studies IF National Academy of Sciences of Ukraine]. 29. 253-265 [in Ukrainian].

43. Maiboroda, O. (2006). Khoch i pro holovne, ale pisnia stara [Although the main thing, but the song is old]. Konhres natsionalnykh hromad Ukrainy [Congress of National Communities of Ukraine]. Forum natsii [Forum of Nations]. URL: http://www.forumn.kiev.ua/Forum34.htm [in Ukrainian].

44. Marchuk, Ye.K. (2016). Na shliakhu do NATO [On the way to NATO]. KyivParyzh-Dakar. 349-354 [in Ukrainian].

45. Nahirnyi, V. (2000). Polityzatsiia rosiiskoi etnichnosti v Ukraini: sproba orhanizatsiinoho oformlennia [Politicization of Russian Ethnicity in Ukraine: An Attempt to Organize]. Naukovi zapysky. Zbirnyk. Seriia "Politolohiia $i$ etnolohiia» [Proceedings. Collection. Political Science and Ethnology Series]. Kyiv. IPiEND. 14. 166-174 [in Ukrainian].

46. Nahorna, L.P. (2011). Sotsiokulturna identychnist: pastky tsinnisnykh rozmezhuvan [Sociocultural identity: traps of value distinction]. Kyiv. IPiEND im. I.F. Kurasa NAN Ukrainy [IPIEND them. IF National Academy of Sciences of Ukraine] [in Ukrainian].

47. (2006). Naukovi zapysky Instytutu politychnykh i etnonatsionalnykh doslidzhen NAN Ukrainy [Scientific notes of the Institute of Political and Ethnic Studies of the NAS of Ukraine]. Kurasivski chytannia-2005. Ser. "Politolohiia $i$ etnolohiia» [Kurasov readings-2005. Avg. "Political Science and Ethnology"]. Kyiv. IPIEND. 30. 1 [in Ukrainian].

48. Panchuk, M., Voinalovych, V., Henyk, M., Kalakura, O., Kotyhorenko, V. ta in. (2000). Natsionalni menshyny Ukrainy u XX stolitti: polityko-pravovyi aspekt [National minorities of Ukraine in the twentieth century: the political and legal aspect]. Kyiv. IPEIND [in Ukrainian].

49. Panchuk, M. \& Rafalskyi, O. (2001). Etnopolityka Ukrainy: dosvid desiatylittia. Ukrainske derzhavotvorennia: uroky, problemy, perspektyvy [Ethno-politics of Ukraine: the experience of the decade. Ukrainian state-building: lessons, problems, prospects]. Materialy naukovo-praktychnoi konferentsii. Lviv: LF UADU [Materials of a scientific-practical conference]. 2. 130-138 [in Ukrainian]. 
50. Pylypenko, T.I. (2008). Stan implementatsii polozhen Ramkovoi Konventsii Rady Yevropy pro zakhyst prav natsionalnykh menshyn v Ukraini [State of implementation of the provisions of the Council of Europe Framework Convention for the Protection of the Rights of National Minorities in Ukraine]. Visnyk derzhkomnatsrelihii Ukrainy [Bulletin of the State Committee for National Religions of Ukraine]. Kyiv. 1. 65-105 [in Ukrainian].

51. (2004). (Problemy intehratsii krymskykh repatriantiv v ukrainske suspilstvo [Problems of integration of Crimean returnees into Ukrainian society]. Zbirnyk materialiv seminaru Kyivskoho proektu instytutu Kennana ta Instytutu politychnykh i etnonatsionalnykh doslidzhen NAN Ukrainy [Proceedings of the Seminar of the Kiev Project of the Kennan Institute and the Institute of Political and Ethnic Studies of the NAS of Ukraine]. 13-14 travnia 2004. Kyiv. Stylos [in Ukrainian].

52. (2004). Problemy intehratsii krymskykh repatriantiv v ukrainske suspilstvo [Problems of integration of Crimean returnees into Ukrainian society]. Materialy Vseukrainskoi naukovopraktychnoi konferentsii [Proceedings of the All-Ukrainian Scientific and Practical Conference]. m. Kyiv, 13-14 travnia 2004. Kyiv. Svitohliad [in Ukrainian].

53. Rafalskyi, O.O. (2000). Natsionalni menshyny Ukrainy u XX stolitti: Istoriohrafichnyi narys [National Minorities of Ukraine in the Twentieth Century: An Historiographical Sketch]. Kyiv. Polius [in Ukrainian].

54. Sahon, O.N. \& Pylypenko, T.I. (2008). (uporiad.) (ed.) Ukraina bahatoetnichna [Ukraine is multi-ethnic]. Derzh. kom. Ukrainy u spravakh natsionalnostei ta relihii [The state. com. Ukraine for Nationalities and Religions]. Kyiv. Svit znan [The world of knowledge] [in Ukrainian].

55. Skliar, A.V. (2009). Pytannia zabezpechennia prav natsionalnykh menshyn yak pryklad asymetrychnosti vzaiemyn u dvostoronnikh vidnosynakh mizh Ukrainoiu ta Rumuniieiu [Issues of securing the rights of national minorities as an example of asymmetry in relations between Ukraine and Romania]. Nauk. Visn. Dyplomatychnoi akademii Ukrainy [Science. Visn. Of the Diplomatic Academy of Ukraine]. 15. 214-220 [in Ukrainian].

56. Strilchuk, L.V. (2009). Pytannia etnichnykh menshyn u vidnosynakh mizh Ukrainoiu ta Polshcheiu [Ethnic minority issues in relations between Ukraine and Poland]. Istorychni studii. Volynskyi nats. Univer-t im. L. Ukrainky [Historical studios. Volyn Nat. Universitet im. L. Ukrainka]. 2009. 6-102 [in Ukrainian].

57. (2009). Suchasna ukrainska polityka [Contemporary Ukrainian politics]. Analitychni dopovidi Instytutu politychnykh $i$ etnonatsionalnykh doslidzhen im. I.F.Kurasa NAN Ukrainy [Analytical Reports of the Institute of Political and Ethnic Studies IF Kuras of the NAS of Ukraine]. Kyiv. IPiEND im. I.F.Kurasa NAN Ukrainy [IPIEND them. IF Kuras of the NAS of Ukraine] [in Ukrainian].

58. Tadieiev, E. \& Buzarov, A. Osetyny yak natsionalna menshyna Ukrainy [Ossetia as a National Minority of Ukraine]. URL: http://www.viche.info/journal/3015/ [in Ukrainian].

59. Todorov, V.I. (2009). Bolhary ukrainskoho Prydunavia: etnohrafichna kharakterystyka [The Bulgarians of the Ukrainian Danube region: an ethnographic characteristic. Author's abstract]. Avtoref

60. Khamula, L. (2008). Stereotypy polsko-ukrainskykh vidnosyn u polskii presi $90-k h \mathrm{rr}$. XX st. - pochatku XXI st. [Stereotypes of Polish-Ukrainian Relations in the Polish Press of the 1990s. - beginning of the XXI century]. Ukraina kulturna spadshchyna, natsionalna svidomist, derzhavnist [Ukraine cultural heritage, national consciousness, statehood]. 17. 618-622 [in Ukrainian].

61. Shypka, N.P. Uhorska natsionalna menshyna u vyborchykh protsesakh nezalezhnoi Ukrainy [Hungarian national minority in the electoral processes of an independent Ukraine]. URL: http://archive.nbuv.gov.ua/portal/Soc_Gum/Npchdu/Politology/2008_66/66-22.pdf n[in Ukrainian]. 
62. Shkvarets, V. Nimtsi pivdennoho rehionu suchasnoi ukrainskoi derzhavy [Germans of the southern region of the modern Ukrainian state]. URL: www.nbuv.gov.uaportalSoc_GumNvmduIst...3...shkvarets.pdf [in Ukrainian].

63. Shcharbak, Yu. (2017). Ukraina v epitsentri svitovoho shtormu: otsinky, prohnozy, komentari [Ukraine in the epicenter of the world storm: estimates, forecasts, comments]. Kyiv. Yaroslaviv Val. 163-164; 211 [in Ukrainian].

64. Shcherba, O. (2012). Krymskotatarska spilnota yak sub'iekt polityky: teoretychnyi aspekt [The Crimean Tatar community as a subject of politics: a theoretical aspect]. Ukrainska natsionalna ideia: realii ta perspektyvy rozvytku [The Ukrainian National Idea: Realities and Prospects for Development]. 24. 138-143 [in Ukrainian].

Одержано 23.05.2019.

УДК 94:[378.147:621.313-051](477) «192»

\author{
Аннснков Ігор, \\ кандидат історичних наук, докторант \\ goalan93@gmail.com \\ http://orcid.org/0000-0002-6642-8048 \\ Національна наукова сільськогосподарська \\ бібліотека Національної академії аграрних \\ наук України, \\ вул. Героїв Оборони, 10, м. Київ, Україна, \\ 03127
}

\section{DOI https://doi.org/10.31470/2415-3567- 2019-46-250-256}

\author{
Annenkov Igor, \\ Candidate of Historical Sciences, \\ doctoral student \\ goalan93@gmail.com \\ http://orcid.org/0000-0002-6642-8048 \\ National Scientific Agricultural Library of the \\ National Academy of Agrarian Sciences of \\ Ukraine, \\ 10, Heroiv Oborony, Kyiv, Ukraine, 03127
}

\section{ОСОБЛИВОСТІ УМОВ ПІДГОТОВКИ НАУКОВО-ТЕХНІЧНИХ КАДРІВ ДЛЯ УКРАЇНСЬКОГО ЕЛЕКТРОМАШИНОБУДУВАННЯ В 1920-Х РР.}

Метою даної статті є визначення основних особливостей умов підготовки науково-технічних кадрів для електромашинобудівної сфери УСРР. За допомогою порівняльно-історичного, діахронічного і синхронічного методів вивчено вплив упродовж 1920-х рр. характеру функціонування українського електромашинобудування в складі єдиного народногосподарського комплексу СРСР на умови підготовки науково-технічних кадрів для иієї галузі. Встановлено, що первісне украӥнський електромашинобудівний сектор не розглядався союзним урядом як одна з рушійних сил розпочатих ним прочесів індустріалізації та електрифікації країни. Причиною изьому стали як брак в украӥнських підприємств власного наукового супроводу виробництва сучасних електричних машин, так $і$ відсутність можливості здійснювати таке забезпечення існуючими в республіці непромисловими профільними науково-технічними підрозділами. При тому розпочався прочес закриття ичих підприємств, який утім не знайтов свого завершення, оскільки в середині 1920-х рр. був зупинений. 3'ясовано, шзо в ией час у Харкові фундується великий осередок виробництва військово-морської електротехніки на основі конструкиій та технологій, наданих німеиькою електротехнічною фірмою «АЕГ». Підставою для изього, в першу чергу, став досвід "АЕГ» у такого роду співробітниитві з Російською імперією напередодні І Світової війни, а також те, щуо підчас иієї війни відповідне устаткування вироблялося на Харківському заводі згаданого конщерну, в наступному в нього секвестрованому. 3 певною затримкою в півтори-два роки, там же був організований 